\title{
CONFORMITY OF REFRIGERATED RAW MILK FROM FAMILY PRODUCTION UNITS OF SOUTHERN ESPÍRITO SANTO
}

\section{CONFORMIDADE DE LEITE CRU REFRIGERADO DE UNIDADES DE PRODUÇÃO FAMILIARES DO SUL DO ESPÍRITO SANTO}

\author{
Leticia Ricieri Bastos ${ }^{1}$ \\ Thallis Abdalla de Oliveira Prata ${ }^{1}$ \\ Fabrizio Raggi Abdallah² \\ Bevaldo Martins Pacheco² \\ Patricia Campos Bernardes ${ }^{1 *}$ \\ Joel Camilo Souza Carneiro ${ }^{1}$ \\ ${ }^{1}$ Universidade Federal do Espírito Santo, Alegre, ES, Brasil. \\ ${ }^{2}$ Instituto Capixaba de Pesquisa, Assistência Técnica e Extensão Rural, Alegre, ES, Brasil. \\ *Corresponding author - paticbernardes@gmail.com
}

\begin{abstract}
Dairy farming is an important activity in Brazil and Espírito Santo state, with small properties accounting for $80 \%$ of production. Despite of this economic importance, data about quality of the milk produced and the hygienic-sanitary conditions are still scarce. Then, the objective of this study was to evaluate the characteristics of refrigerated raw milk produced in family production units in southern Espírito Santo to verify compliance with Brazilian legal standards. Three collections were carried out in 29 community expansion tanks, for a total of 87 samples of refrigerated raw milk. Analysis of standard plate count (SPC), psychrotrophic bacteria count (PBC), somatic cell count (SCC), titratable acidity, density, fat, total dry extract (TDE), non-fat dry extract (NFDE), residues of antibiotics ( $\beta$-lactam and tetracycline), cadmium and lead levels were performed. Of the 87 samples, 66\% presented non-standard values for SPC, and 38\% had non-standard values for SCC. Eighty five percent of the samples presented non-standard results for NFDE, $10.3 \%$ for density and $2.3 \%$ for titratable acidity. All samples complied with the legislation regarding residues of antibiotics, $\mathrm{Cd}$ and $\mathrm{Pb}$ levels. These results indicated failures in the raw milk obtainment and storage chain from family production units of southern Espírito Santo, Brazil.
\end{abstract}

Keywords: Milk quality, community expansion tanks, small producers of milk.

\section{Resumo}

A pecuária de leite é uma atividade importante no Brasil e no Espírito Santo, sendo as pequenas propriedades responsáveis por $80 \%$ da produção estadual. Mesmo com essa importância econômica para o estado, dados a respeito da qualidade do leite produzido e das condições higiênico-sanitárias de produção, ainda são escassos. Objetivou-se avaliar a qualidade do leite produzido em unidades de produção familiares, no sul do Espírito Santo, para verificar o atendimento aos padrões legais. Foram realizadas três coletas em 29 tanques comunitários totalizando 87 amostras. Realizaram-se análises 
de contagem padrão em placa (CPP), contagem de bactérias psicrotróficas (CBP), contagem de células somáticas (CCS), acidez titulável, densidade, gordura, extrato seco total (EST), extrato seco desengordurado (ESD), pesquisa de resíduos de antibióticos ( $\beta$-lactâmicos e tetraciclina) e presença de cádmio e chumbo. Das 87 amostras, 66\% apresentaram valores fora do padrão para CPP e 38\% para CCS. Quanto às análises físico-químicas, $85 \%$ das amostras apresentaram resultados fora do padrão para ESD, 10,3\% para densidade e 2,3\% para acidez titulável. Todas as amostras atenderam a legislação quanto a presença de resíduos de antibióticos, teores de cádmio e chumbo. Dessa forma, esses resultados indicam falhas em uma ou mais etapas da cadeia de obtenção e armazenamento do leite cru.

Palavras-chave: Qualidade do leite, tanques de expansão comunitários, pequenos produtores de leite.

Received on: February, $2^{\text {nd }}, 2108$.

Accepted on: July, $9^{\text {th }}, 2018$.

\section{Introduction}

The quality of refrigerated raw milk is of great importance to the industry, as it directly affects the quality and durability of dairy products, as well as risks to consumer health ${ }^{(1,2)}$. In Brazil, in 2002, the Ministry of Livestock and Food Supply (MAPA) approved Normative Instruction (NI) number 51, with physicochemical parameters (titratable acidity, fat content, relative density and non-fat dry extract) and microbiological parameters (standard plate count and somatic cell count) for refrigerated raw milk, with deadlines for meeting the requirements based on region in the country ${ }^{(3)}$. Considering that the great majority of dairy farmers in Brazil found difficult to comply with the legislation, in 2011, the Federal Government approved the Normative Instruction number 62 that extended the deadlines for compliance for standard plate count and somatic cell count ${ }^{(4)}$. Even currently, studies have shown that producers still find difficult to meet such standards ${ }^{(5,6)}$.

Despite the quality of the milk to be of great importance, it should be noted that there are very few published studies with this type of data from the southern region of Espírito Santo, Brazil. Therefore, the objective of the work was to carry out microbiological and physicochemical analysis of the raw refrigerated milk coming from family production units in southern Espírito Santo to verify compliance with the current legal standards.

\section{Materials and Methods}

Twenty-nine community expansion tanks that collected milk from family production units in thirteen cities in the southern of Espírito Santo were selected (Alegre, Apiacá, Atílio Vivácqua, Bom Jesus do Norte, Cachoeiro de Itapemirim, Castelo, Ibitirama, Jeronimo Monteiro, Mimoso do Sul, Muqui, Presidente Kennedy, Rio novo do Sul, and São José dos Calçados). Refrigerated raw milk samples were collected in sterilized glass bottles and transported to the laboratory in isothermal boxes from March to September 2016 and submitted to microbiological analysis of standard plate count (SPC), psychrotrophic bacteria count (PBC) and somatic cell count (SCC). Physicochemical analysis of 
titratable acidity, fat, relative density, total dry extract (TDE) and non-fat dry extract (NFDE) were conducted. Analysis of antibiotic residues of $\beta$-lactam and tetracycline and the presence of cadmium $(\mathrm{Cd})$ and lead $(\mathrm{Pb})$ were also carried out. Three samples were collected in each tank, for a total of 87 samples. The collections were carried out on different days and at intervals of at least one week.

SPC and PBC were performed on 3M TM Petrifilm TM Plates (Sumaré, Brazil) for aerobic counts, according to the manufacturer's recommendations. One milliliter aliquot of milk at the proper dilution was transferred to the plate. The SPC plates were incubated at $35^{\circ} \mathrm{C}$ for 48 hours. For PBC plates were incubated at $7{ }^{\circ} \mathrm{C}$ for 10 days. SCC were performed using the IDEXX Somaticell SCC Test Kit (São Paulo, Brazil) according to the manufacturer's recommendations. SPC and SCC results were compared to Normative Instruction 62/2011 of MAPA ${ }^{(4)}$. In Brazil, currently, there is no legislation that determines PBC in raw milk. According to literature reports, it is recommended to avoid the use of raw milk with psychrotrophic counts above $5.7 \mathrm{log}$ of colony-forming units per milliliter (cfu.mL $\mathrm{mL}^{-}$ ${ }^{1}$ ) in the manufacture of dairy products ${ }^{(7)}$, so this value was used to compare our results.

Physicochemical analysis of titratable acidity, relative density, fat, TDE and NFDE were performed according to the methodology prescribed in Normative Instruction 68/2006 of MAPA ${ }^{(8)}$.

The presence of $\beta$-lactam and tetracycline residues in milk was verified using a test kit for antibiotics, BetaStar ${ }^{\circledR}$ Combo (Neogen, Esher, England) according to the manufacturer's recommendations.

For $\mathrm{Cd}$ and $\mathrm{Pb}$ analysis milk samples were digested in a MARS 6 (CEM Corporation, Matthews, USA) using MARSX press tubes. A total of $0.5 \mathrm{~g}$ of lyophilized raw milk sample was added, and 10 $\mathrm{mL}$ of $65 \%$ PA nitric acid (Vetec, Rio de Janeiro, Brazil) was added according to the methodology described by Klimek et al. ${ }^{(9)}$. The digestion was performed between $180{ }^{\circ} \mathrm{C}$ and $210{ }^{\circ} \mathrm{C}$, with a ramp time of 20 to 25 minutes, and a hold time of 15 minutes, as recommended by the manufacturer for organic samples. After digestion, the samples were diluted to $25 \mathrm{~mL}$ with milli-Q water. Calibration curves were prepared from standard solutions of $1000 \mathrm{mg} \mathrm{L}^{-1}$ of $\mathrm{Cd}$ and $\mathrm{Pb}$ (Merck, Darmstadt, Germany), with a maximum concentration of $1.0 \mathrm{mg} \mathrm{mL}^{-1}$. The samples were analysed in a flame atomic absorption spectrophotometer (Varian, São Paulo, Brazil), model Spectra 220 FS.

Data were tabulated, and descriptive statistics are presented in table form. The results of the analysis of raw milk were compared with the current legislation: Normative Instruction 62/2011 and Decree number $9.013 / 2017$ of MAPA ${ }^{(4,10)}$ and, 55.871/1965 and Ordinance number 685/1998 of Ministry of Health ${ }^{(11,12)}$.

\section{Results and Discussion}

SPC of raw milk is related to hygiene and sanitation practices in milking, including the hygiene of equipment and utensils, cleanliness of milking equipment, water quality used in hygiene processes and quality of the storage conditions ${ }^{(2)}$, assiduity of milker, poor hygiene, absence of ceilings, inadequate milk cooling, storage for more than 48 hours, and sanity of the herd ${ }^{(7,13)}$.

SPC of refrigerated raw milk from the expansion tanks ranged from less than 4.0 to 7.7 log of cfu $\mathrm{mL}^{-1}$ (Table 1). NI 62/2011 of MAPA sets a maximum SPC of $3.0 \times 10^{5} \mathrm{cfu} \mathrm{mL}^{-1}$ or $5.5 \log$ of cfu mL- 
${ }^{1}$ for the south-eastern region of Brazil ${ }^{(4)}$. Of the 87 samples evaluated, 66\% (57) had SPC above the legal standard (Table 1). A similar result was obtained in four community tanks in the city of AlegreES, Brazil by Nascimento Neta et al. ${ }^{(14)}$ wherein $50 \%$ (02) of the tanks had SPC above legislation recommendations. Different results were found by Almeida et. al. ${ }^{(15)}$ who obtained non-standard SPC in all of 326 raw milk samples from northern of Minas Gerais, Brazil. The authors associated this result with possible management failures, such as unsatisfactory sanitary practices in the hygiene of utensils and water quality.

Table 1. Minimum and maximum of standard plate count (SPC), psychrotrophic bacteria count (PBC) and somatic cell count (SCC) of 87 samples of refrigerated raw milk from community expansion tanks in southern Espirito Santo, Brazil in 2016

\begin{tabular}{|c|c|c|c|c|c|}
\hline Analyses & $\begin{array}{l}\text { Minimum } \\
\text { count }\end{array}$ & $\begin{array}{l}\text { Maximum } \\
\text { count }\end{array}$ & $\begin{array}{l}\text { Medium } \\
\text { count }\end{array}$ & Standard & $\begin{array}{l}\text { Non- } \\
\text { standard } \\
\text { samples }\end{array}$ \\
\hline $\mathrm{SPC}\left(\log \mathrm{cfu} \mathrm{mL}^{-1}\right)$ & $<4.0$ & 7.7 & 5.8 & $\leq 5.5$ (a) & $66 \%$ \\
\hline PBC (log cfu mL-1) & $<3.0$ & 7.1 & 4.7 & $\leq 5.7(b)$ & $16 \%$ \\
\hline SCC (log somatic cells $\left.\mathrm{mL}^{-1}\right)$ & 5.0 & 6.3 & 5.7 & $\leq 5.7$ (a) & $38 \%$ \\
\hline
\end{tabular}

Pinto et al. ${ }^{(7)}$ analysed raw refrigerated milk of 33 individual expansion tanks, 12 communities tanks, and one industrial silo in Zona da Mata Mineira. They found that SPC in the industrial silo was higher than allowed by legislation. However, the same was not true for samples from individual expansion tanks. The authors attributed this difference to possible additional contamination and bacterial multiplication during transportation and storage in the industrial silo.

According to Marcondes et al. ${ }^{(16)}$, the lower the production of the herd, the greater is the SPC. As most of the producers participating in this research were small and with low productivity animals, it was expected that a great part of the samples presented high values for SPC. The increase in SPC occurs due to faults in hygienic-sanitary conditions during milking ${ }^{(17)}$. These failures are probably due to the lower incidence of trained workers in small farms ${ }^{(18)}$.

The presence of psychrotrophic microorganisms in refrigerated raw milk may cause problems in reducing the durability of dairy products. This occurs because psychrotrophic microorganisms cause deterioration, and some producing enzymes (proteolytic and lipolytic) also cause degradation of dairy products. Many of these are heat resistant and cause changes in the products during their storage ${ }^{(7,19)}$.

Considering previous research ${ }^{(7)}$ and that raw milk can be storage at the dairy industry for some hours before being processed, the value of $5.7 \log$ of $\mathrm{cfu} \mathrm{mL}^{-1}$ was chosen to be the acceptable maximum value for PBC in this study. The PBC of the raw milk from the expansion tanks ranged from less than 3.0 to $7.1 \log$ of cfu $\mathrm{mL}^{-1}$. Of the 87 samples evaluated, $16 \%$ (14) presented PBC above $5.7 \log$ of cfu $\mathrm{mL}^{-1}$ (Table 1).

Fox ${ }^{(20)}$ reports that problems with yield and off-flavour in cheeses due to the activity of proteolytic psychrotrophic appear when counts are above $6.0 \log$ of $\mathrm{cfu} \mathrm{mL}^{-1}$. Muir et al. ${ }^{(21)}$ concluded that in order to not affect the quality of dairy products, the psychrotrophic count in milk should be less than 
or equal to $6.3 \log$ of cfu $\mathrm{mL}^{-1}$.

Nascimento Neta et al. ${ }^{(14)}$ found that $25 \%(01)$ of the four community expansion tanks evaluated in the city of Alegre-ES, presented psychrotrophic bacterial count above $5.7 \log$ of cfu $\mathrm{mL}^{-1}$.

Ângelo et al. ${ }^{(22)}$ studied four individual and four collective tanks in São João Nepomuceno-MG, Brazil. Two of the community tanks presented a psychrotrophic bacteria count above $5.0 \log$ of cfu $\mathrm{mL}^{-1}$, value that was considered high by the authors.

Low counts of psychrotrophic bacteria, as observed in the most samples of our study, can be explained by factors such as low initial contamination of raw milk or the collection of samples when the milk had little storage time under refrigeration, leading to insufficient time for the multiplication of psychrotrophic microorganisms. As in the present study, high SPC were observed we believed that the time that milk remained under refrigeration was not sufficient for the multiplication of psychrotrophic microorganisms since the bacterial initial populations was generally high.

High SCC in milk negatively influences its quality, altering its constituents and reducing the durability of dairy products made with that milk. All this generates losses for the dairy industry. Increasing in SCC indicate inflammation in the mammary gland that leads to reduced volume produced, raise proteolytic and lipolytic activity of milk, changes in membrane permeability with consequent loss of components for bloodstream. This results in changes in the milk composition, especially in lactose, casein and mineral salts affecting the yield of dairy products. In addition, it has a public health concern, once mastitis can be caused by pathogenic microorganisms as staphylococci and streptococci $(20,23)$.

All this causes damage to the dairy industry, since they occur in changes in the chemistry of milk, especially in lactose and mineral salts, in the yield of dairy products. In addition, it has a public health problem, since mastitis can be published by pathogenic microorganisms, for example, of the genus Staphylococcus.

The samples of refrigerated raw milk from expansion tanks presented SCC ranging from 5.0 to 6.3 $\log$ of somatic cells $\mathrm{mL}^{-1}$ (Table 1). The NI 62/2011 sets a maximum value of 5.0x10 $0^{5}$ somatic cells per milliliter or $5.7 \mathrm{log}$ of somatic cells $\mathrm{mL}^{-1}$ for the south-eastern region of Brazill(4). Of the 87 refrigerated raw milk samples, 38\% (33) had SCC (Table 1) above the maximum allowed by the legislation $^{(4)}$.

Results founded by others researchers were better then ours. Angelis et al. ${ }^{(24)}$ founded that only $11 \%$ (02) of the 18 raw milk samples obtained from manual or mechanical milking in Argirita-MG, Brazil were outside of the standard. Alves et al. ${ }^{(25)}$ collected 32 samples of milk from refrigerated tanks in Colorado do Oeste-RO, Brazil between 2010 and 2013, and verified the counts within the standard set by the current legislation for all samples.

The somatic cell count is related to mastitis, which is an inflammation of the mammary glands often caused by pathogenic and/or deteriorating bacteria. Blood leukocytes spread to the mammary glands to fight against the infectious agent, causing somatic cell elevation ${ }^{(26,27)}$.

The incidence of mastitis in lactating animals is influenced by several factors, such as climate (temperature and humidity), genetics, age, lactation period, animal handling and nutrition ${ }^{(28)}$. Climatic factors, such as high temperatures and high humidity (rainy season), contribute to the increased 
incidence of mastitis and consequently to increasing the SCC in milk ${ }^{(29,30)}$.

Considering that the sampling period was almost completely during the dry season (low humidity), a lower incidence of mastitis was expected in the herds. Moreover, the years of 2015 and 2016 were marked by a severe drought in the state of Espírito Santo.

In instances of mastitis, diseased animals may be in the process of being diagnosed or treated, and the milk produced from that animal must be discarded. Cows with higher milk production tend to have higher SCC values. Besides, some factors may increase predisposition to mastitis, such as stress due to the retention time of the animals, the time interval between the disinfection of the teats and the beginning of milking and maintenance of calves at foot of the cow ${ }^{(31)}$.

Titratable acidity is a rapid and quantitative analysis used to evaluate the quality of raw milk ${ }^{(33)}$. Bacteria present in milk ferment lactose producing lactic acid, which increases the titratable acidity ${ }^{(34)}$. Therefore, this test is widely used to check the quality of raw milk. In the analysis of titratable acidity, only $2.3 \%(02)$ of the samples fell outside the range recommended by the legislation (i.e., 0.14-0.18 g of lactic acid $100 \mathrm{~mL}^{-1}$ ) (Table 2).

Table 2. Minimum and maximum values of physicochemical analysis of 87 samples of raw milk from expansion tanks in southern Espirito Santo, Brazil in 2016

\begin{tabular}{llllll}
\hline Analyses & $\begin{array}{l}\text { Minimum } \\
\text { value }\end{array}$ & $\begin{array}{l}\text { Maximum } \\
\text { value }\end{array}$ & $\begin{array}{l}\text { Medium } \\
\text { value }\end{array}$ & Standard & $\begin{array}{l}\text { Non- } \\
\text { standard } \\
\text { samples }\end{array}$ \\
\hline Titratable acidity (a) & 0.13 & 0.21 & 0.16 & $0.14-0.18(\mathrm{c})$ & $2.3 \%$ \\
Relative density (b) & 1.026 & 1.032 & 1.028 & $1.028-1.034(\mathrm{c})$ & $10.3 \%$ \\
Fat (\%) & 3.0 & 4.7 & 3.9 & $\geq 3.0$ (c) & $0.0 \%$ \\
Total dry extract (\%) & 10.9 & 13.8 & 12.0 & $\geq 11.4($ (d) & $7.0 \%$ \\
Non-fat dry extract (\%) & 7.3 & 9.2 & 8.1 & $\geq 8.4($ c) & $85.0 \%$ \\
\hline
\end{tabular}

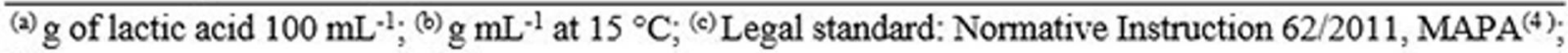

(d) Decree $9.013 / 2017$, MAPA $^{(10)}$.

For relative density at $15^{\circ} \mathrm{C}$ all values fell between 1.026 and $1.032 \mathrm{~g} \mathrm{~mL}^{-1}$ (Table 2). Approximately $10 \%$ (09) of the samples were below the range stipulated by the legislation (i.e., $\left.1.028-1.034 \mathrm{~g} \mathrm{~mL}^{-1}\right)^{(4)}$. The density is strongly affected by the NFDE. The relationship is directly proportional; that is, a reduction in the NFDE causes a reduction in the relative density. As in our work was observed low level of NFDE for $85 \%$ of samples this factor could explain this finding. Another factor that affects the relative density is the fat content; but they are inversely related, when the fat content increases, the density decreases ${ }^{(34,38,40)}$. In the state of Paraná, Brazil 5.4\% (04) of the raw milk samples tested were outside of the standard for relative density ${ }^{(39)}$. According to the authors, samples with low relative density occurred because of fraud by the water addition. However, it is known that other factors can cause variations in milk density. In addition, the values above the range occurred because the samples had a fat content below $3.0 \%$, which is the minimum legally allowed ${ }^{(39)}$.

Milk composition as well as its fat content can be influenced by several factors, such as nutrition, race, lactation stage, season and animal health, but the most influential factor is nutrition ${ }^{(32)}$.

In the analysis of the fat content of refrigerated raw milk, the values ranged from 3.0 to $4.7 \%$ (Table 
2). All 87 samples presented values within the standards set by the legislation (i.e., $\geq 3.0 \%)^{(10)}$.

Total dry extract (TDE) corresponds to all components of milk except water. Among them, the most relevant are fat and protein, which directly affects the yield of dairy products and are therefore of great interest to the industry ${ }^{(35)}$. TDE of raw milk ranged from 10.9 to $13.8 \%$. The NI $62 / 2011$ does not stipulate values for TDE in refrigerated raw milk, but Decree 9013 article 248 of March 29, 2017, states that raw milk must contain at least $11.4 \% \mathrm{TDE}^{(10)}$. Seven percent (06) of the samples had TDE values below $11.4 \%$ (Table 2). In analysis of twenty samples of refrigerated raw milk from bulk tank trucks in the southern of Rio de Janeiro, Brazil, Paula et al. ${ }^{(36)}$ did not observe any TDE values below $11.4 \%$. Variations in TDE may occur due to herd genetics and health, lactation stage, animal age, diet and season. Variations in milk composition are common among different breeds. Among the components, fat usually suffers the most variation. In the first three months of lactation, the levels of fat, protein and lactose are lower, after that period levels increase gradually. The older the animal, the lower the productivity of the mammary glands and the greater the chances of inflammation. The diet given to the animal influences the composition of the milk, since the ingested nutrients will be absorbed and used in the formation of milk components. High temperatures cause a decrease in the fat content of the milk; in addition, stress due to high temperatures causes the reduction of dry matter intake by the animals, affecting milk composition ${ }^{(37,38)}$.

The NFDE is composed mainly of lactose and protein and therefore also affects the yield of dairy products. In addition to acidity and density, NFDE is also used to detect milk fraud. Eighty five percent (74) of the samples of refrigerated raw milk had levels below those recommended by the legislation (i.e., $\geq 8.4 \%$ ) (Table 2). The values ranged from 7.3 to 9.2\%. Molina et al. ${ }^{(41)}$ analysed samples from 21 producers of raw milk from Itaqui-RS, Brazil. They found that $62 \%$ (13) of the samples were outside the legal standard. The authors stated that variations in NFDE may be due to variations in animal feeding or variations caused by mastitis.

In this study the NFDE was the parameter with the highest percentage of samples that were outside of the limits set by the legislation. The breed and age of the animal, stage of lactation, feeding and sanity of the herd can alter the levels of NFDE in milk ${ }^{(42)}$. Considering that in 2015 and 2016, the State of Espírito Santo faced the worst drought in the last 40 years ${ }^{(43)}$ we believed that the results for NFDE have been influenced by the water crisis. Due to the drought, some farmers gave up dairy farming, and many found difficult to feed their herds, causing great variations in the feeding of the animals and altering the composition of the milk and consequently its quality.

The use of antibiotics in lactating animals is common for the treatment of mastitis, however, the period required to prevent residues of the drug in milk should be respected ${ }^{(44)}$. None of the samples tested were positive for $\beta$-lactam or tetracycline antibiotics. This result shows that milk producers probably did not add milk from cows being treated with this type of drug to the expansion tank or that the levels of these antibiotics in the milk were below the detection limit of the test used. Nascimento Neta et al. ${ }^{(14)}$ carried out two collections in four community expansion tanks in the city of Alegre-ES, Brazil and did not detect residues of antibiotics in refrigerated raw milk. Different results were found by Souza et al. ${ }^{(45)}$, in which $6.7 \%$ of 112 samples of raw milk from six cities in the state of Rio Grande do Norte, Brazil presented positive results for residues of several antimicrobials. The presence of antibiotics in milk not only causes damage to the industry of fermented dairy products, but also is dangerous to consumer health, due to the selection of resistant bacterial strains, 
hypersensitivity and possible anaphylactic shock in allergic persons ${ }^{(44)}$.

Investigation of the presence of heavy metals such as $\mathrm{Cd}$ and $\mathrm{Pb}$ has received much attention because of the toxicity of these metals ${ }^{(46,47,48)}$. Children are more sensitive to the action of these metals, which is problematic, since they are the main consumers of milk and dairy products ${ }^{(49)}$. Heavy metals, such as $\mathrm{Cd}$ and $\mathrm{Pb}$ may be present in soil, water, feed and pasture, and, once supplied to cows, can reach the blood and milk. This contamination may occur due to industrial activity, use of pesticides, or transportation from one location to another by road and rail ${ }^{(50,51)}$. None of the refrigerated raw milk samples showed levels of $\mathrm{Cd}$ or $\mathrm{Pb}$ outside of the legal limits. According to brazilian legislation, the maximum limit for $\mathrm{Pb}$ in fluid milk is $0.05 \mathrm{mg} \mathrm{kg}^{-1}{ }^{(12)}$. For $\mathrm{Cd}$, there is no legal limit specific to milk, but there is a maximum limit for food in general, which is $1.0 \mathrm{mg} \mathrm{kg}^{-1(11)}$. Other studies did not detect Cd concentrations above the detection limit in South Africa which is of $0.006 \mu \mathrm{g} / \mathrm{L}^{(52)}$, Italy which is $0.018 \mathrm{ng} / \mathrm{mL}$, Vale do Paraíba, São Paulo, Brazil ${ }^{(53)}$, or in India that is of $0.8-1.0 \mu \mathrm{g} / \mathrm{kg}$ for infants through milk ${ }^{(49)}$. On the other hand, Soares et al. ${ }^{(53)}$ detected levels of $\mathrm{Pb}$ above what is allowed by brazilian legislation in 92\% (50) of milk samples collected in the state of São Paulo. These authors justified that contamination in the water and pastures of the Vale do Paraíba-SP, Brazil were caused by a lead ingot industry, installed in the state in 1979.

\section{Conclusions}

The main problems observed in the raw milk samples are related to the high counts of total bacteria, high somatic cell count and the lack of compliance with the standards of the legislation for most physicochemical parameters. These results show that there are failures in one or more steps in the chain of obtaining and storing raw milk under refrigeration. Because of this, training and incentives to the milk producers are needed to improve milk quality from family production units of southern Espírito Santo, Brazil.

\section{Acknowledgements}

The authors would like to acknowledge Incaper (Instituto Capixaba de Pesquisa, Assistência Técnica e Extensão Rural) for the partnership as well as the Federal University of Viçosa, MG, Brazil, for assistance in the analysis of cadmium and lead. This work was financially supported by Fapes (Fundação de Amparo à Pesquisa e Inovação do Espírito Santo, Brazil), Grant number: 65564464/ 2014.

\section{References}

1. Brito MAVP, Brito JRF. Capítulo 3 - Qualidade do leite. In: Manejo: Cuidados que fazem a diferença. 1st ed. São Paulo: Embrapa-CNPGL/Tortuga; 1998; p. 43-5. Portuguese.

2. Chye FY, Abdullah A, Ayob MK. Bacteriological quality and safety of raw milk in Malaysia. Food Microbiol [Internet]. 2004 [cited $2017 \quad$ Mar 15]; 21(5):535-41. Available from: http://www.sciencedirect.com/science/article/pii/S0740002003001163. 
3. Brasil. Ministério da Agricultura Pecuária e Abastecimento. Instrução Normativa $N^{\circ} 51$ de 18 de setembro de 2002. Aprova os Regulamentos Técnicos de Produção, Identidade e Qualidade do Leite tipo A, do Leite tipo B, do Leite tipo C, do Leite Pasteurizado e do Leite Cru Refrigerado e o Regulamento Técnico da Coleta de Leite Cru Refrigerado e seu Transporte a Granel. 2002. Portuguese.

4. Brasil. Ministério da Agricultura Pecuária e Abastecimento. Instrução Normativa $N^{o}$ 62, de 29 de dezembro de 2011.Aprovar o Regulamento Técnico de Produção, Identidade e Qualidade do Leite tipo A, o Regulamento Técnico de identidade e Qualidade de Leite Cru Refrigerado, o Regulamento Técnico de Identidade e Qualidade de Leite Pasteurizado e o Regulamento Técnico da Coleta de Leite Cru Refrigerado e seu Transporte a Granel, em conformidade com os Anexos desta Instrução Normativa. 2011. Portuguese.

5. Nascimento Neta FCN, Junqueira M da S, Carneiro JCS, Ramos M da PP, Abdallah FR, Fracalossi CP. Condições de Produção de Leite em Propriedades Familiares Localizadas no Município de Alegre - ES, Brasil. [Conditions of milk production of family farms located in the municipality of Alegre - ES, Brazil]. Revista Instituto Laticínios Cândido Tostes [Internet]. 2015 [cited 2017 Mar 15]; 70(3):117-31. Available from: https://www.revistadoilct.com.br/rilct/article/view/347. Portuguese.

6. Simioni FJ, Lopez LS, Nespolo CR, Stefani LM, Bordignon R, Bittelbrun MS. Season influence on milk physico-chemical and microbiological aspects in Western Santa Catarina. Semina Ciências Agrárias [Internet]. 2014 [cited 2017 Mar 15]; 35(4):2033-46. Available from: http://www.redalyc.org/articulo.oa? id=445744142028.

7. Pinto CL de O, Martins ML, Vanetti MCD. Qualidade microbiológica de leite cru refrigerado e isolamento de bactérias psicrotróficas proteolíticas. [Microbial Quality of Raw Refrigerated Milk and Isolation of Psychrotrophic Proteolytic Bacteria]. Ciência e Tecnologia de Alimentos [Internet]. 2006 [cited 2017 Feb 03]; 26(3):645-51. Available from: http://www.scielo.br/scielo.php?script=sci abstract\&pid=S010120612006000300025\&lng=en\&nrm=iso\&tlng=pt. Portuguese.

8. Brasil. Ministério da Agricultura Pecuária e Abastecimento. Instrução Normativa № 68 , de 12 de dezembro de 2006. Oficializa os Métodos Analíticos Oficiais Físico-Químicos, para Controle de Leite e Produtos Lácteos, em conformidade com o anexo desta Instrução Normativa, determinando que sejam utilizados nos Laboratórios Nacionais Agropecuários. 2006. Portuguese.

9. Klimek B, Sitarz A, Choczyński M, Niklińska M. The Effects of Heavy Metals and Total Petroleum Hydrocarbons on Soil Bacterial Activity and Functional Diversity in the Upper Silesia Industrial Region (Poland). Water Air Soil Pollut [Internet]. 2016 [cited 2017 Mar 15]; 227(8):265. Available from: https://link.springer.com/article/10.1007/s11270-016-2966-0.

10. Brasil. Ministério da Agricultura Pecuária e Abastecimento. Decreto No. 9013, de 29 de março de 2017. Regulamenta a Lei $n^{0} 1.283$, de 18 de dezembro de 1950, e a Lei ${ }^{\circ} 7.889$, de 23 de novembro de 1989, que dispõem sobre a inspeção industrial e sanitária de produtos de origem animal. 2017. Portuguese.

11. Brasil. Ministério da Saúde. Decreto $n^{\circ} 55871$, de 26 de março de 1965. Modifica o Decreto ${ }^{0} 50.040$, de 24 de janeiro de 1961, referente a normas reguladoras do emprego de aditivos para alimentos, alterado pelo Decreto $n^{\circ}$ 691, de 13 de março de 1962. 1965. Portuguese.

12. Brasil. Ministério da Saúde. Portaria n ${ }^{\circ}$ 685, de 27 de agosto de 1998. Aprova o Regulamento Técnico: "Princípios Gerais para o Estabelecimento de Níveis Máximos de Contaminantes Químicos em Alimentos" e seu Anexo: "Limites máximos de tolerância para contaminantes inorgânicos". 1998. Portuguese.

13. Guerreiro PK, Machado MRF, Braga GC, Gasparino E, Franzener A da SM. Qualidade Microbiológica de Leite em Função de Técnicas Profiláticas no Manejo de Produção. [Microbiological quality of milk through preventive techniques in the handling of production]. Ciência e Agrotecnologia [Internet]. 2005 [cited 2017 Mar 15]; 29(1):216-22. Available from: http://www.scielo.br/scielo.php?script=sci_abstract\&pid=S1413- 
$\underline{70542005000100027 \& \operatorname{lng}=\text { en\&nrm }=\text { iso \&tlng }=\text { pt. Portuguese. }}$

14. Nascimento Neta FCC do, Junqueira M da S, Carneiro JCS, Ramos M da PP, Pinto CL de O, Rosário DKA. Avaliação da Qualidade de Leite Cru Armazenado em Tanques de Refrigeração no Município de Alegre, Espírito Santo. Revista Brasileira de Agropecuária Sustentável (RBAS) [Internet]. 2016 [cited 2017 Dec 13]; 6(3). Available from: http://www.rbas.com.br/index.php/rbas/article/view/333. Portuguese.

15. Almeida AC de, Santos CA dos, Menezes IR, Teixeira LM, Costa JPR, Souza RM de. Perfil Sanitário de Unidades Agrícolas Familiares Produtoras de Leite Cru e Adequação à Legislação Vigente. Ciência Animal Brasileira [Internet]. 2016 [cited 2017 Dec 13]; 17(3) Available from: http://www.scielo.br/scielo.php?pid=S1809-68912016000300303\&script=sci_abstract Portuguese.

16. Marcondes MI, Brandão VLN, Ferreira GAT, Silva AL da, Marcondes MI, Brandão VLN, et al. Impacto do tamanho da propriedade na qualidade do leite na indústria leiteira brasileira de acordo com as estações do ano. Ciência Rural [Internet]. 2017 [cited 2017 Dec 13]; 47(11). Available from: http://www.scielo.br/scielo.php?pid=S0103-84782017001100451\&script=sci abstract\&tlng=pt. Portuguese.

17. Bueno VFF, Mesquita AJ de, Oliveira AN, Nicolau ES, Neves RBS. Contagem bacteriana total do leite: relação com a composição centesimal e período do ano no Estado de Goiás. [Total bacterial count: relationship to milk composition and period of the year in Goiás State, Brazil]. Revista brasileira de Ciências Veterinárias [Internet]. 2008. [cited 2017 Mar 15]; 15 (1): 40-44. Available from: http://www.rbcv.uff.br/rbcv/article/view/363. Portuguese.

18. Valeeva NI, Meuwissen MPM, Bergevoet RHM, Lansink O, M AGJ, Huirne RBM. Improving Food Safety at the Dairy Farm Level: Farmers' and Experts' Perceptions. Review of Agricultural Economics [Internet]. 2005 [cited 2017 Dec 13]; 27(4):574-92. Available from: http://www.rbcv.uff.br/rbcv/article/view/363.

19. Zeni MP, Maran MH de S, Silva GP rabaioli da, Carli EM de, Palezi SC. Influência dos Microrganismos Psicrotróficos Sobre a Qualidade do Leite Refrigerado para Produção de UHT. Unoesc \& Ciência[Internet]. 2013 [cited 2017 Mar 15]; 4(1):61-70. Available from: http://editora.unoesc.edu.br/index.php/acet/article/view/2111. Portuguese.

20. Fox PF. Proteolysis During Cheese Manufacture and Ripening. Journal of Dairy Science [Internet]. 1989 [cited 2017 Mar 15]; 72(6):1379-400. Available from: www.journalofdairyscience.org.

21. Muir DD, Griffiths MW, Phillips JD, Sweetsur AWM, West IG. Effect of the bacterial quality of raw milk on the bacterial quality and some other properties of low-heat and high-heat dried milk. International Journal of Dairy Technology [Internet]. 1986 [cited 2017 Mar 15]; 39(4):115-8. Available from: http://onlinelibrary.wiley.com/doi/10.1111/j.1471-0307.1986.tb02394.x/abstract.

22. Ângelo FF, Ribeiro C de S, Oliveira L de, Araujo TF de, Cardarelli HR. Bactérias Psicrotróficas em Leite Cru Refrigerado. Revista Científica de Medicina Veterinária [Internet]. 2014 [cited 2017 Mar 15]; (Ano XIINúmero 22):1-14. Available from: http://faef.revista.inf.br/imagens arquivos/arquivos destaque/7HHKldbMr5M7pdW 2014-2-8-9-26-18.pdf. Portuguese.

23. Langoni H. Tendências de modernização do setor lácteo: monitoramento da qualidade do leite pela contagem de células somáticas. [Modernization trends in the dairy industry: milk quality monitoring by somatic cell counts]. Revista de Educação Continuada em Medicina Veterinária e Zootecnia do CRMV-SP [Internet]. 2000 [cited 2017 Mar 15]; 3(3):57-64. Available from: http://revistas.bvsvet.org.br/recmvz/article/view/3332. Portuguese.

24. Angelis D, Sousa MRP de, Oliveira V. Qualidade do leite, obtido por ordenha manual e mecanizada, 
recebido em um laticínio do município de Argirita MG. Veterinária Notícias [Internet]. 2016 [cited 2017 Mar 15]; 3127-3127. Available from: file:///C:/Users/Leticia/Zotero/storage/G72F8SI8/vti-15236.html. Portuguese.

25. Alves E da C, Dahmer AM, Borges AF. Total bacterial count and somatic cell count in refrigerated raw milk stored in communal tanks. Brazilian Journal of Food Technology [Internet]. 2014 [cited 2017 Mar 15]; 17(3):221-5. Available from: $\quad$ http://www.scielo.br/scielo.php?script=sci abstract\&pid=S1981$67232014000300006 \& \operatorname{lng}=$ en\&nrm=iso\&tlng=en.

26. Saeman AI, Verdi RJ, Galton DM, Barbano DM. Effect of mastitis on proteolytic activity in bovine milk. Journal of Dairy Science [Internet]. 1988 [cited 2017 Mar 23]; 71(2):505-12. Available from: https://www.ncbi.nlm.nih.gov/pubmed/3288655.

27. Watts JL. Etiological agents of bovine mastitis. Veterinary Microbiology. 1988 [cited 2017 Mar 23]; 16(1):41-66. Available from: https://www.ncbi.nlm.nih.gov/pubmed/3354192.

28. Prestes DS, Filappi A, Cecim M. Susceptibilidade à mastite: Fatores que a influenciam - Uma revisão. [Factors Affecting Mastitis Susceptibility: A Revision] Revista da FZVA [Internet]. 2002 [cited 2017 Mar 23]; 9(1). Available from: http://revistaseletronicas.pucrs.br/ojs/index.php/fzva/article/view/2153. Portuguese.

29. Morse D, DeLorenzo MA, Wilcox CJ, Collier RJ, Natzke RP, Bray DR. Climatic effects on occurrence of clinical mastitis. Journal of Dairy Science [Internet]. 1988 [cited 2017 Mar 23]; 71(3):848-53. Available from: http://www.sciencedirect.com/science/article/pii/S0022030288796265?via\%3Dihub

30. Ribeiro Neto AC, Barbosa SBP, Jatobá RB, Silva AM, Silva CX, Silva MJA, et al. Qualidade do leite cru refrigerado sob inspeção federal na região Nordeste. [Quality of bulk tank milk with federal inspection fro]. Arquivo Brasileiro de Medicina Veterinária e Zootecnia [Internet]. 2012 [cited 2017 Mar 23]; 64(5):1343-51. Available from: $\quad$ http://www.scielo.br/scielo.php?script=sci abstract\&pid=S0102$\underline{09352012000500035 \& \operatorname{lng}=\mathrm{pt} \& n r m=i \text { so } \& \text { tlng }=\text { pt. }}$ Portuguese.

31. Gonzalez SG, Müller EE, Ribeiro EL de A, Freitas JC de, Godoy AL de. Influência de fatores raciais e manejo nutricional na contagem de células somáticas e nos constituintes do leite de vacas holandesas e mestiças no Norte do Estado do Paraná, Brasil. [Influence of racial and nutritional management factors on somatic cells count and milk composition of Holstein and mixed breed cows in the north of Paraná State, Brazil]. Acta Scientiarum. Animal Sciences. 2008 [cited 2017 Dec 13]; 25(2):323-9. Available from: http://www.periodicos.uem.br/ojs/index.php/ActaSciAnimSci/article/view/2016 Portuguese.

32. Looper ML. Factors Affecting Milk Composition of Lactating Cows - FSA4014 - Semantic Scholar. FAO [Food and Agriculture Organization of the United Nations]. 2012 [cited 2017 Mar 23]. Available from: https://www.uaex.edu/publications/pdf/FSA-4014.pdf.

33. Schmidt KA, Stupar J, Shirley JE, Adapa S, Sukup D. Factors affecting titratable acidity in raw milk. Kansas Agricultural Experiment Station. Kansas Agricultural Experiment Station Research Reports. 1996 [cited 2017 Mar 23]. 0 (2). Available from: http://newprairiepress.org/kaesrr/vol0/iss2/340/.

34. Fox PF, McSweeney PLH. Dairy Chemistry and Biochemistry. 1st ed. London; New York: Springer; 1998.

35. Tronco VM. Manual Para Inspeção De Qualidade Do Leite. 2nd ed. UFSM; 2010.

36. Paula FP de, Cardoso CE, Rangel MAC. Análise Físico-química do Leite Cru Refrigerado Proveniente das Propriedades Leiteiras da Região Sul Fluminense. [Physical Chemistry Analysis of Milk Refrigerated Row Proceeding of Propriety Milkmaid Region of South Fluminense] Revista Eletrônica TECCEN [Internet]. 2010 [cited 2017 Mar 23]; 3(4):07-17. Available from: http://editorauss.uss.br/index.php/TECCEN/article/view/257. Portuguese. 
37. Smit G, editor. Dairy Processing: Improving Quality. 1 edition. Cambridge: Woodhead Publishing; 2003.

38. Walstra P, Wouters JTM, Geurts TJ. Dairy Science and Technology, Second Edition. 2 edition. Boca Raton: CRC Press; 2005.

39. Ribeiro Júnior JC, Beloti V, Silva LCC da, Tamanini R. Avaliação da qualidade microbiológica e físicoquímica do leite cru refrigerado produzido na região de Ivaiporã, Paraná. [Evaluation of microbiological and physicochemical quality of raw refrigerated milk produced in Ivaiporã-PR region- Brazil] Revista do Instituto Laticínios Cândido Tostes [Internet]. 2013 [cited 2017 Mar 23]; 68(392):5-11. Available from: https://www.revistadoilct.com.br/rilct/article/view/23. Portuguese.

40. Poonia A, Jha A, Sharma R, Singh HB, Rai AK, Sharma N. Detection of adulteration in milk: A review. International Journal of Dairy Technology [Internet]. 2017 [cited 2017 Dec 20]; 70(1):23-42. Available from: http://onlinelibrary.wiley.com/doi/10.1111/1471-0307.12274/abstract.

41. Molina CHA, Centenaro GS, Furlan VJM. Qualidade do leite cru comercializado informalmente no município de Itaqui-RS. [Quality of raw milk informally sold in the city of Itaqui, Rio Grande do Sul, Brazil]. Vigilância Sanitária Em Debate: Sociedade, Ciência e Tecnologia [Internet]. 2015 [cited 2017 Mar 25]; 3(4):106-13. Available from: https://visaemdebate.incqs.fiocruz.br/index.php/visaemdebate/article/view/492. Portuguese.

42. Koblitz MGB. Leite. In: Matérias-Primas Alimentícias. Composição e Controle de Qualidade. Edição: 1a . Guanabara Koogan; 2011. Portuguese.

43. Espírito Santo [Governo do Estano]. Governador quer consolidar políticas públicas sobre uso e produção de água. Portal ES [Internet]. 2016 [cited 2017 Dec 13]. Available from: https://www.es.gov.br/Notícia/governador-quer-consolidar-politicas-publicas-sobre-uso-e-producao-de-agua. Portuguese.

44. Ibraimi Z, Shehi A, Murtezani A, Krasniqi S, Agani Z. Kosovo's Public Health Damage from Abusive Use of Antibiotics in Dairy Cattle. Mater Sociomedica [Internet]. 2015 [cited 2017 Mar 25]; 27(3):149-53. Available from: https://www.ncbi.nlm.nih.gov/pmc/articles/PMC4499300/.

45. Souza LB de, Pinheiro CGM da E, Neto SAG, Silva JBA da. Resíduos de Antimicrobianos em Leite Bovino Cru no Estado do Rio Grande do Norte. [Antimicrobial Residues in Bovine Milk in Natura in Rio Grande do Norte]. Ciência Animal Brasileira [Internet]. 2017 [cited 2017 Dec 8]; 18(0). Available from: https://www.revistas.ufg.br/vet/article/view/e-23050. Portuguese.

46. Martino FAR, Sánchez MLF, Medel AS. Total determination of essential and toxic elements in milk whey by double focusing ICP-MS. Journal of Analytical Atomic Spectrometry [Internet]. 2000 [cited 2017 Mar 25]; 15(2):163-8. Available from: http://pubs.rsc.org/en/content/articlelanding/2000/ja/a907925d.

47. Onianwa P., Adetola I., Chukwujindu I, Ojo M., Tella O. Trace heavy metals composition of some Nigerian beverages and food drinks. Food Chemistry [Internet]. 1999 [cited 2017 Mar 25]; 66:275-9. Available from: https://www.sciencedirect.com/science/article/pii/S030881469800257X.

48. Somers E. The Toxic Potencial of Trace Metals in Foods. A Review. Journal of Food Science [Internet]. 1974 [cited 2017 Mar 25]; 39(2):215-7. Available from: http://onlinelibrary.wiley.com/doi/10.1111/j.13652621.1974.tb02860.x/abstract.

49. Tripathi RM, Raghunath R, Sastry VN, Krishnamoorthy TM. Daily intake of heavy metals by infants through milk and milk products. Science of The Total Environment [Internet]. 1999 [cited 2017 Mar 25]; 227(2):229-35. Available from: http://www.sciencedirect.com/science/article/pii/S0048969799000182.

50. Licata $\mathrm{P}$, Trombetta D, Cristani M, Giofrè F, Martino D, Calò M, et al. Levels of "toxic" and "essential" metals in samples of bovine milk from various dairy farms in Calabria, Italy. Environment International 
[Internet]. 2004 [cited 2017 Mar 25]; 30(1):1-6. Available from: http://www.sciencedirect.com/science/article/pii/S0160412003001399?via\%3Dihub.

51. Tajkarimi M, Ahmadi Faghih M, Poursoltani H, Salah Nejad A, Motallebi AA, Mahdavi H. Lead residue levels in raw milk from different regions of Iran. Food Control [Internet]. 2008 [cited 2017 Mar 25]; 19(5):4958. Available from: http://www.sciencedirect.com/science/article/pii/S0956713507001181.

52. Ataro A, McCrindle RI, Botha BM, McCrindle CME, Ndibewu PP. Quantification of trace elements in raw cow's milk by inductively coupled plasma mass spectrometry (ICP-MS). Food Chemistry [Internet]. 2008 [cited 2017 Mar 25]; 111(1):243-8. Available from: http://www.sciencedirect.com/science/article/pii/S030881460800352X.

53. Soares VA, Kus MMM, Peixoto ALC, Carrocci JS, Salazar RFS, Izário Filho HJ. Determination of nutritional and toxic elements in pasteurized bovine milk from Vale do Paraiba region (Brazil). Food Control [Internet]. 2010 [cited 2017 Mar 25]; 21(1):45-9. Available from: http://www.sciencedirect.com/science/article/pii/S0956713509000991. 